\title{
Seasonal Response of Daphnia pulex to Cyanobacterial Extracts at Different Temperatures in Valle de Bravo Reservoir (Mexico)
}

\author{
S. Nandini *(D), Carlos Sánchez-Zamora (D) and S. S. S. Sarma \\ Laboratorio de Zoología Acuática, División de Investigación y Posgrado, Universidad Nacional Autónoma de \\ México, Campus Iztacala, Av. de los Barrios \# 1, Los Reyes Iztacala, Tlalnepantla, CP 54090 Estado de México, \\ Mexico; cas_aza@hotmail.com (C.S.-Z.); sarma@unam.mx (S.S.S.S.) \\ * Correspondence: nandini@unam.mx
}

Citation: Nandini, S.;

Sánchez-Zamora, C.; Sarma, S.S.S. Seasonal Response of Daphnia pulex to Cyanobacterial Extracts at Different Temperatures in Valle de Bravo Reservoir (Mexico). Water 2021, 13, 526. https://doi.org/10.3390/ w13040526

Academic Editor: George Arhonditsis Received: 13 January 2021

Accepted: 11 February 2021

Published: 18 February 2021

Publisher's Note: MDPI stays neutral with regard to jurisdictional claims in published maps and institutional affiliations.

Copyright: (c) 2021 by the authors. Licensee MDPI, Basel, Switzerland. This article is an open access article distributed under the terms and conditions of the Creative Commons Attribution (CC BY) license (https:/ / creativecommons.org/licenses/by/ $4.0 /)$.

\begin{abstract}
Valle de Bravo reservoir supplies drinking water to $40 \%$ of Mexico City. Here we present data on the population growth and life-table demography of the cladoceran Daphnia pulex, cultured at temperatures of $20^{\circ} \mathrm{C}$ and $25^{\circ} \mathrm{C}$ and with different concentrations of the crude extracts from blooms of Microcystis aeruginosa, collected in January, and Woronichinia naegeliana, collected in September. We hypothesized that Daphnia pulex would be more sensitive at the higher temperature and to toxins from $W$. naegeliana as these blooms have been shown to be more toxic to rotifers. We extracted the toxins and conducted acute toxicity tests at eight concentrations of microcystins at $20^{\circ} \mathrm{C}$. The LC50 was $26.8 \mu \mathrm{g} / \mathrm{L}$ and $11.5 \mu \mathrm{g} / \mathrm{L}$, respectively, for Microcystis and Woronichinia samples. The chronic toxicity tests included population growth and life-table demography studies at 5 and $10 \%$ of the LC50 concentration, at $20^{\circ} \mathrm{C}$ and $25^{\circ} \mathrm{C}$. Four replicates for each of the three treatments, which consisted of treatments with low and high cyanotoxin levels and a control without cyanotoxins, were set up. The population growth rate ranged from 0.18 to $0.42 \mathrm{~d}^{-1}$ on the extracts from M. aeruginosa (January) and from 0.2 to 0.31 on extracts from W. naegeliana. Daphnia, being better adapted to cooler temperatures, was more adversely affected at $25^{\circ} \mathrm{C}$ than $20^{\circ} \mathrm{C}$. The adverse effect of cyanobacterial extracts was greater from Microcystis than Woronichinia blooms. The tolerance of Daphnia pulex to cyanotoxins depends on the bloom-forming species and the temperature.
\end{abstract}

Keywords: cyanotoxins; cladoceran; life table; population growth; acute toxicity test; temperature

\section{Introduction}

Several large lakes and reservoirs in Mexico have dense cyanobacterial for most of the year. Valle de Bravo is an important reservoir in the State of Mexico which supplies drinking water to $40 \%$ of the people in the Mexico City Metropolitan Area. Over the past decades, this reservoir has been subject to several anthropogenic stressors including high nutrient inputs and changes in water level and temperature patterns. These have led to the presence of practically permanent cyanobacterial blooms, particularly of the genera Microcystis, Dolichospermum, Woronichinia and Lyngbya [1]. Similar conditions have been reported in another waterbody, Lake Zumpango, also in the State of Mexico, with dense blooms of Microcystis and Planktothrix. Water temperature in Lake Zumpango too has risen by more than one degree over the past 15 years. However, water from this lake is used only for irrigation and aquaculture. In Valle de Bravo reservoir, microcystin concentrations above the WHO permissible limits for potabilization $(1 \mu \mathrm{g} / \mathrm{L})$ have been recorded [2,3], while, in Lake Zumpango, bioaccumulation of microcystins in the fish consumed locally has been reported [4].

Acute and chronic toxicity tests are currently used to assess the effects of cyanotoxins in reservoirs. Rotifer bioassays have been used to test the toxicity of pure microcystins [5] and showed that Brachionus calyciflorus can withstand up to $200 \mu \mathrm{g} / \mathrm{L}$ of microcystins. In nature, however, several different genera of cyanobacteria co-occur [1]. These produce different cyanotoxins; for instance, Microcystis, Lyngbya, Dolichospermum and Woronichinia 
all occur together but each produces different secondary metabolites, such as microcystins, cylindrospermopsin, anatoxins and microginins. These compounds may have synergistic effects in nature and one method of assessing this is by testing crude extracts from a bloom rather than purified toxins from a single species [6]. Some cyanobacteria produce compounds that inhibit digestive proteases in animals [7].

The effect of cyanobacterial extracts have been tested on zooplankton for more than a decade $[8,9]$. Several studies are available on the effects of extracts from cultured Dolichospermum planctonicum, originally isolated from Valle de Bravo reservoir, and natural cyanobacterial blooms from freshwater and saline lakes and reservoirs on different zooplankton species, such as Brachionus calyciflorus, Plationus patulus, Brachionus havanaensis and Ceriodaphnia dubia [10-13]. Most ecotoxicological assays on cladocerans are conducted using Daphnia magna. This species is, however, not found in Mexican freshwater; nevertheless, Daphnia pulex is widely distributed in Mexican ponds and lakes. Therefore, it is important to conduct ecotoxicological assays on D. pulex using different contaminants in order to create a database of information about its sensitivity. A study comparing the sensitivity of cladoceran neonates and adults including Daphnia pulex, Daphnia similis and Daphnia laevis showed that D. pulex was the most sensitive to heavy metal and pesticide toxicity [14].

One of the adverse effects of climate change, as regards the increase in mean temperature, is the presence of persistent cyanobacterial blooms. In Valle de Bravo reservoir, cyanobacterial blooms have been persistent over the past 20 years $[1,15]$. The toxic effects of cyanobacteria are evaluated using different methods. Life-table demography and population growth studies are some of the sensitive tools used to assess the effect of environmental variables on zooplankton [16] and thereby assess the health of the ecosystem. Several studies indicate that life history variables, especially population growth rate, are adversely affected when a zooplankton species is subjected to temperatures outside its preferred range and that there is a synergistic interaction of contaminants with temperature $[17,18]$.

Considering the importance of the Valle de Bravo reservoir as a source of drinking water, it is important to find quick and sensitive assays to test water quality, especially since the reservoir is known to have blooms of more than ten species of cyanobacteria, including Microcystis, Planktothrix, Lyngbya, Dolichospermum and Merismopedia, among others [1]. There is a considerable seasonality to these blooms. Microcystis aeruginosa, M. flos aquae and $M$. wesenbergii dominate during hot, dry summers, while Dolichospermum dominate in winters and Woronichinia during the rainy period. The common rotifers and cladocerans in this reservoir are Keratella cochlearis, Polyarthra vulgaris, Trichocerca similis and Bosmina longirostris. The zooplankton densities in this reservoir vary depending on the species composition and the season $[3,15,17]$.

Our objective in the present study was to analyse the population growth and life table demography of Daphnia pulex cultured at temperatures of $20^{\circ} \mathrm{C}$ and $25^{\circ} \mathrm{C}$ and with different concentrations of the crude extracts from blooms of Microcystis aeruginosa, collected in January, and Woronichinia naegeliana, collected in September. A previous study showed that these extracts were toxic to the rotifer Brachionus calyciflorus [12]. We hypothesized that the sensitivity of Daphnia pulex would be greater at the higher temperature and to toxins from $W$. naegeliana, as the blooms tend to be more toxic, perhaps due to the high predation pressure they are subjected to in the summer.

\section{Materials and Methods}

\subsection{Study Site}

Valle de Bravo reservoir is located east of Toluca city in the State of Mexico, at an altitude of 1780 masl $\left(19^{\circ} 11^{\prime} 38.71^{\prime \prime} \mathrm{N}\right.$ and $\left.100^{\circ} 09^{\prime} 02.59^{\prime \prime} \mathrm{W}\right)$. It has a volume of $418.25 \times 10^{6} \mathrm{~m}^{3}$, a surface area of $18.55 \mathrm{~km}^{2}$ and a mean depth of $21.1 \mathrm{~m}$ [15]. It is one of the main sources of drinking water for a large section of the population in Mexico City. 


\subsection{Sample Collection}

One composite sample was collected during the dry season (10th of January, 2017) and one during the rainy season (19th of September, 2017), near the dam (Figure 1).
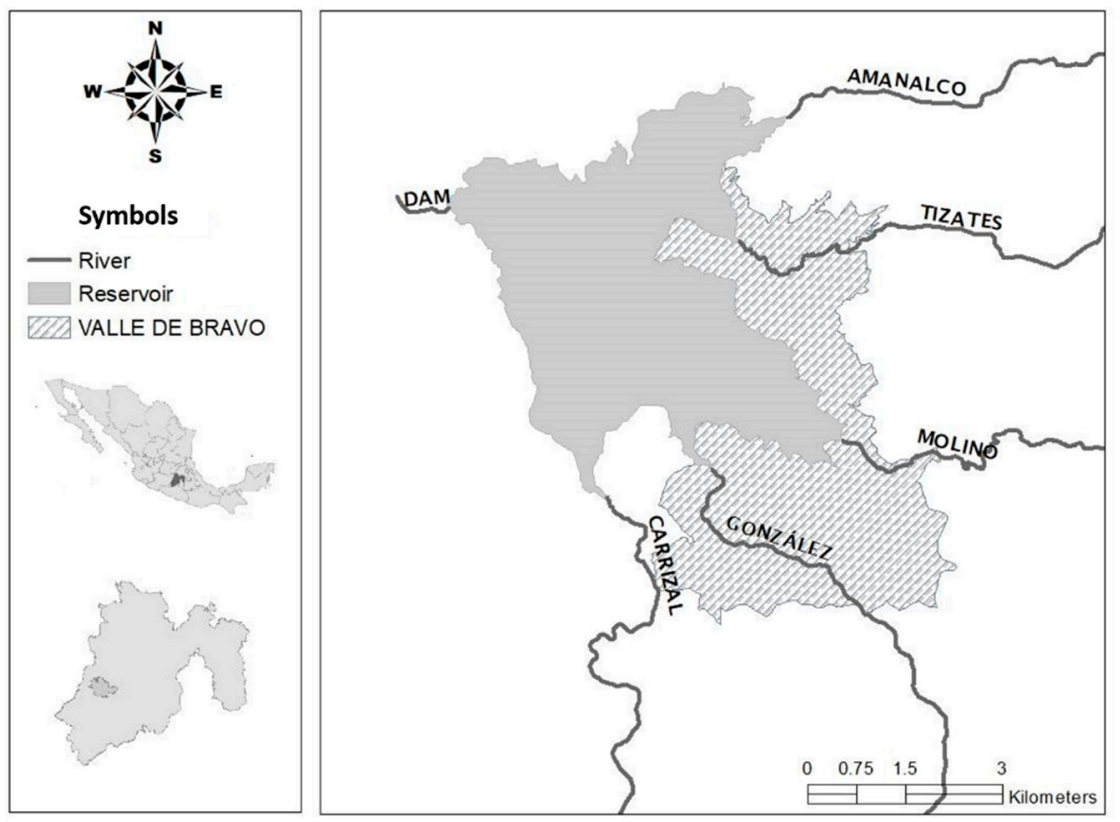

Figure 1. Map of Valle de Bravo Reservoir highlighting the lake basin, rivers entering the reservoir and the collection site (dam).

We collected water for the experiments depending on the density of the bloom: $20 \mathrm{~L}$ from a dense bloom in January and $150 \mathrm{~L}$ from a less dense bloom in September. The samples were concentrated and crude aqueous extract prepared in the laboratory.

\subsection{Identification and Quantification of the Cyanobacteria}

From the samples collected above we fixed a subsample of $100 \mathrm{~mL}$ in $3 \%$ formalin for taxonomical analyses. The dominant cyanobacteria were identified following Komárek et al. [19] and Wehr and Sheath [20] and quantified using a Sedgewick Rafter Counting Chamber.

\subsection{Preparation of the Crude Extract}

We filtered the blooms collected in January and September through a mesh of $150 \mu \mathrm{m}$ to remove small algae and diatoms and retain only large colonial cyanobacteria. The cyanobacterial biomass was frozen and stored at $-20{ }^{\circ} \mathrm{C}$ for two days, thawed at room temperature and then sonicated for $10 \mathrm{~min}$ at $14 \mathrm{MHz}$. The biomass was again frozen and the cycle repeated five times, following Pietsch et al. [9]. After that the extract was centrifuged at $4000 \mathrm{rpm}$ for $30 \mathrm{~min}$ to remove the debris and filtered through a $0.45 \mu \mathrm{m}$ Millipore filter. Finally, we stored the extract at $-20^{\circ} \mathrm{C}$ for later use. We determined the concentration of microcystins in the extract using the ELISA assay by EnviroLogix ${ }^{\mathrm{TM}}$.

\subsection{Cultures}

The zooplankton cultures were maintained on Chlorella vulgaris and Scenedesmus acutus grown in 2 L PET bottles, using the Bold basal medium [21], to which we added $0.5 \mathrm{~g}$ of $\mathrm{NaHCO}_{3}$ every three days as a source of carbon. The cultures were maintained under constant aeration and fluorescent illumination (4300 lux). The algae were harvested during the exponential phase of their growth (normally eight days after inoculation), sedimented, decanted and re-suspended in distilled water prior to use. 
Daphnia pulex was isolated from the Chimaliapan Wetland (State of Mexico) and a clone was established. We maintained the daphniid cultures in moderately hard water $\left(1.98 \mathrm{~g}\right.$ of $\mathrm{NaHCO}_{3}, 1.2 \mathrm{~g}$ of $\mathrm{CaSO}_{4}, 1.2 \mathrm{~g}$ of $\mathrm{MgSO}_{4}$ and $0.04 \mathrm{~g}$ of $\mathrm{KCL}$ in $20 \mathrm{~L}$ of distilled water) [22]. The cladocerans were fed Scenedesmus acutus at a density of $0.5 \times 10^{6}$ cells $/ \mathrm{mL}$, determined based on estimations using a haemocytometer.

\subsection{Acute Toxicity Tests}

To determine the median lethal concentration, we set up eight concentrations of microcystins $(3.82,7.65,11.48,15.30,19.13,22.96,26.78$ and $30.61 \mu \mathrm{g} / \mathrm{L}$ for the January samples and $0.85,1.71,2.56,3.42,4.27,5.13,5.98$ and $6.84 \mu \mathrm{g} / \mathrm{L}$ for the September samples) in $50 \mathrm{~mL}$ containers with $25 \mathrm{~mL}$ of the test medium. Scenedesmus acutus at $0.5 \times 10^{6}$ cells $/ \mathrm{mL}$ served as food. To each container we introduced five neonates of Daphnia pulex. We also set up controls without any crude extract but only pure EPA medium and algal diet. For each treatment we used four replicates; experiments were conducted in an incubator set at $20^{\circ} \mathrm{C}$ and after $24 \mathrm{~h}$ we counted the number of dead individuals from each test jar. The LC50 was derived from the mortality data using the probit method [23].

\subsection{Chronic Toxicity Tests}

Chronic toxicity tests involving population growth and life-table demography were conducted at 5 and $10 \%$ of the LC50; these corresponded to 6.7 and $13.4 \mu \mathrm{g} / \mathrm{L}$ and 11.83 and $23.66 \mu \mathrm{g} / \mathrm{L}$ for the January and September samples, respectively. Both, the population growth and life-table experiments were conducted in $100 \mathrm{~mL}$ vessels containing $50 \mathrm{~mL}$ of EPA medium with $C$. vulgaris at $0.5 \times 10^{6}$ cells $/ \mathrm{mL}$ at $20^{\circ} \mathrm{C}$ and $25{ }^{\circ} \mathrm{C}$. Four replicates for each of the three treatments, which consisted of low and high cyanotoxin levels and a control without cyanotoxins, were set up. Experiments were initiated with five individuals of a mixed population of neonates, juveniles and adults of female Daphnia pulex for the population growth study or five neonates $<24$-h old for the life-table demography tests. We counted the total number of individuals for the population growth experiments daily and transferred the living individuals to a fresh medium with appropriate food and toxin concentrations daily until a declining trend in the population density was observed. Based on the data collected, we calculated the population growth rate following [24]:

$$
r=\frac{\left(\ln N_{t}-\ln N_{0}\right)}{t}
$$

where $r$ is the daily population growth rate, $N_{t}$ is the number of individuals after time $t, N_{0}$ is the initial population density and $t$ is the time in days.

For the life-table demography experiments, we counted and transferred the living individuals of the original cohort to a fresh medium with chosen food and toxin concentrations; neonates and dead adults when encountered were counted but discarded. The experiment was discontinued when all individuals of the original cohort died.

Based on the data, we calculated the following variables:

- $\quad$ age-specific survivorship $\left(l_{x}\right)=$ proportion of the original cohort surviving at the start of age $x$;

- $\quad$ age-specific reproduction $\left(m_{x}\right)=$ offspring produced per female at age $x$;

- $\quad$ average life span:

$$
e_{x}=\frac{T_{x}}{n_{x}}
$$

where $T_{x}$ is the cumulative number of individuals from age $x$ to the maximum age and $n_{x}$ is the number of live individuals at the start of age $x$ (days); Gross reproductive rate:

$$
\sum_{0}^{\infty} m x
$$


Net reproductive rate:

$$
R_{0}=\sum_{0}^{\infty} l x \cdot m x
$$

Generation time:

$$
T=\frac{\sum x \cdot l x \cdot m x}{R_{0}}
$$

Rate of population increase:

$$
\sum_{x=w}^{n} e^{-r x} \cdot l x \cdot m x=1
$$

where $r$ is the rate of population increase per day and $w$ is the age at maturity (days).

Data on the population abundances were statistically compared using repeated measures ANOVA, two-way ANOVA and post-hoc Tukey tests.

\section{Results}

The phytoplankton blooms from the Valle de Bravo reservoir were dominated by Microcystis aeruginosa in January, during the dry season, and by Woronichinia naegeliana in September, after the rains.

The population growth of Daphnia pulex was generally higher in the presence of the crude extract than in controls (Figure 2). Regardless of the temperature, the cladoceran reached higher densities in the presence of the extracts from Woronochinia (total density of 180-220 ind.) than from Microcystis aeruginosa (around 150 ind.). An adverse effect for $W$. naegeliana was observed only at $25^{\circ} \mathrm{C}$ and at a concentration of $23.66 \mu \mathrm{g} / \mathrm{L}$.

The population growth rate ranged from 0.18 to $0.42 \mathrm{~d}^{-1}$ for the extracts from $M$. aeruginosa (January) and from 0.2 to $0.31 \mathrm{~d}^{-1}$ for extracts from $W$. naegeliana. Generally, the growth rates of Daphnia were significantly greater $(p<0.05$, F-test) in the presence of the extracts than in the controls. Population growth rates of Daphnia were generally higher at $20^{\circ} \mathrm{C}$ than at $25^{\circ} \mathrm{C}$. The tolerance to $W$. naegeliana extracts was higher at $25^{\circ} \mathrm{C}$ than at $20^{\circ} \mathrm{C}$ and, with the higher concentration of the extract, the growth rates decreased significantly.

The survivorship (Figure 3) of Daphnia pulex was longer (around 40 days) at $20^{\circ} \mathrm{C}$ but was reduced to around 30 days at $25^{\circ} \mathrm{C}$. The adverse effects of the toxins on survivorship, regardless of the season, were greater at $25{ }^{\circ} \mathrm{C}$ than at $20{ }^{\circ} \mathrm{C}$. There was a significant decrease in the survivorship, as compared to the controls, during tests in both seasons $(p<0.05$, Gehan Breslow Log Rank test).

The reproduction patterns (Figure 3) in Daphnia pulex revealed that the offspring production was earlier and higher in treatments with cyanotoxins as compared with controls at both $20^{\circ} \mathrm{C}$ and $25^{\circ} \mathrm{C}$. In extracts from blooms collected in September with a dominance of Woronichinia, the fecundity was greater than that in the controls at both the tested temperatures. Regardless of the cyanotoxin concentration, fecundity of D. pulex was greater at $20^{\circ} \mathrm{C}$ than at $25^{\circ} \mathrm{C}$. 


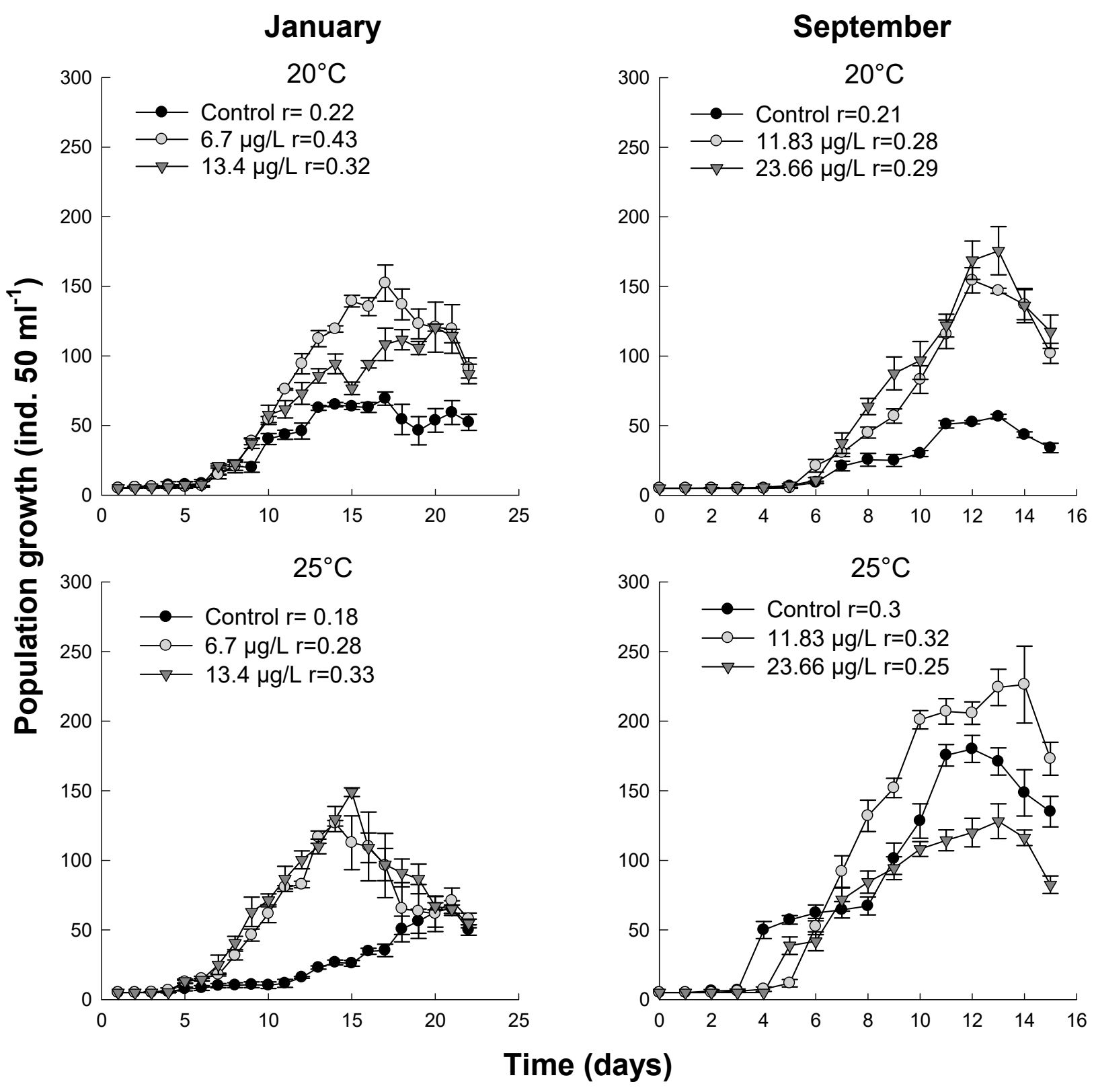

Figure 2. Population growth of Daphnia pulex exposed to cyanobacterial extracts from blooms of Microcystis (January) and Woronichinia (September) at $20^{\circ} \mathrm{C}$ and $25^{\circ} \mathrm{C}$. Shown are the means $\pm \mathrm{SE}$ based on four replicate recordings.

The average life span and life expectancy at birth in the presence of the Microcystisdominant blooms were significantly lower at the $13.4 \mu \mathrm{g} / \mathrm{L}$ microcystin concentration as compared to controls or the lower microcystin concentration $(6.7 \mu \mathrm{g} / \mathrm{L}(p<0.05$, one-way ANOVA) (Figure 4). Similar trends were observed in the gross and net reproductive rates, as well as in the generation time. The population growth rates ranged between 0.20 to $0.35 \mathrm{~d}^{-1}$ but were significantly higher ( $p<0.05$, one-way ANOVA) in the presence of low or high concentrations of microcystins as compared to the controls (Figure 4). 

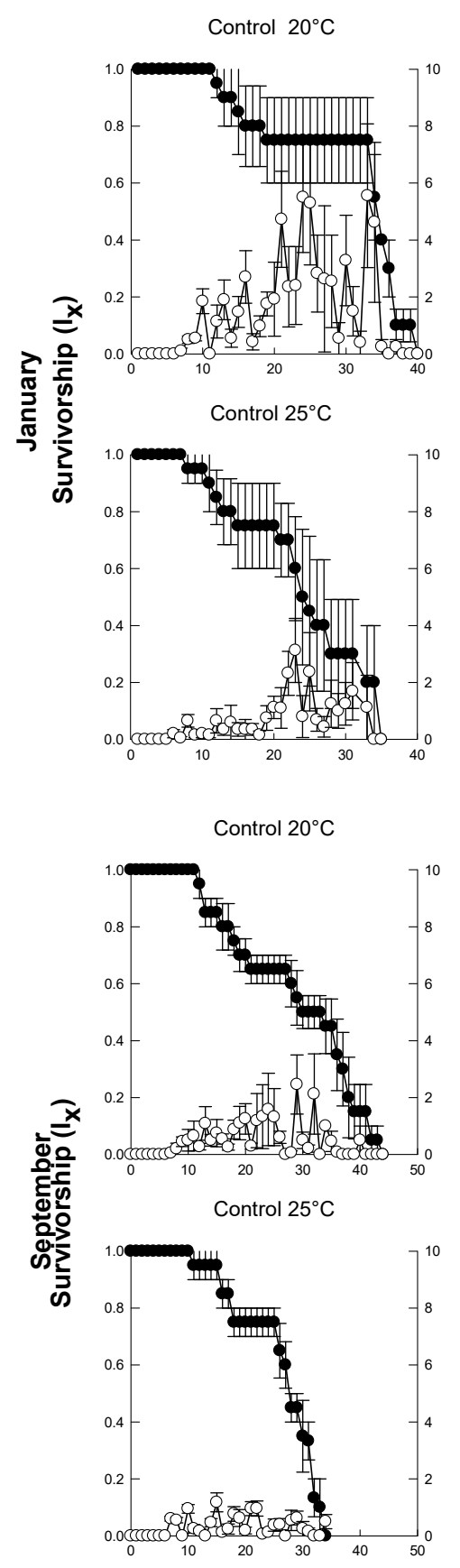

$6.7 \mu \mathrm{g} / \mathrm{L} 20^{\circ} \mathrm{C}$

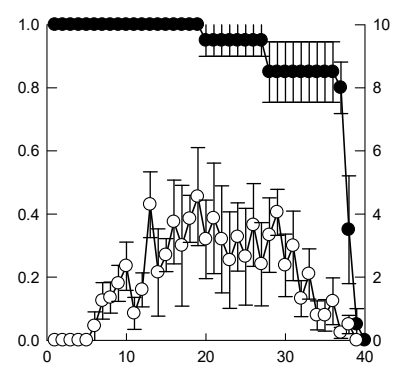

$6.7 \mu \mathrm{g} / \mathrm{L} 25^{\circ} \mathrm{C}$

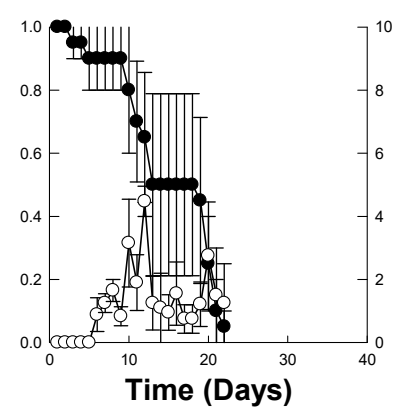

$11.83 \mu \mathrm{g} / \mathrm{L} 20^{\circ} \mathrm{C}$

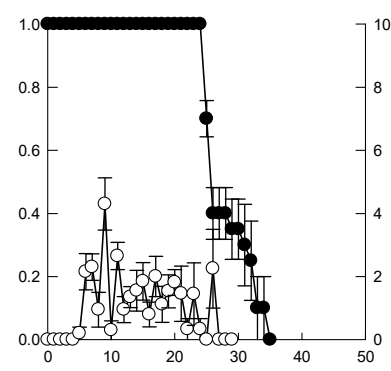

$11.83 \mu \mathrm{g} / \mathrm{L} 25^{\circ} \mathrm{C}$

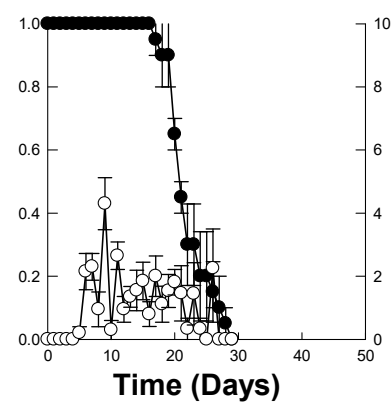

$\because-$ Survivorship

Fecundity

$13.4 \mu \mathrm{g} / \mathrm{L} 20^{\circ} \mathrm{C}$

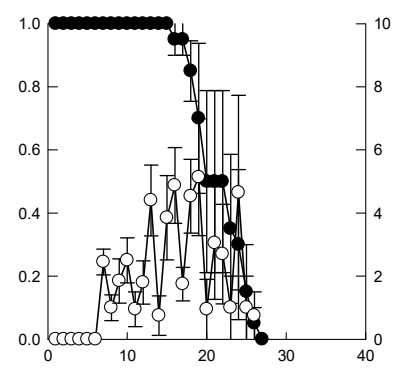

$13.4 \mu \mathrm{gg} / \mathrm{L} 25^{\circ} \mathrm{C}$

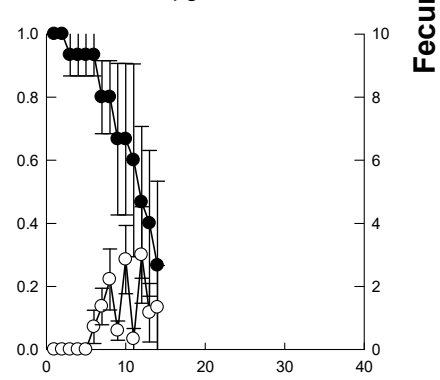

$23.66 \mu \mathrm{g} / \mathrm{L} 20^{\circ} \mathrm{C}$

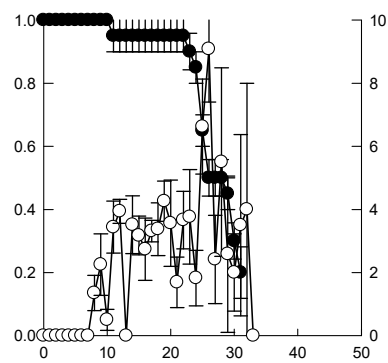

$23.66 \mu \mathrm{g} / \mathrm{L} 25^{\circ} \mathrm{C}$

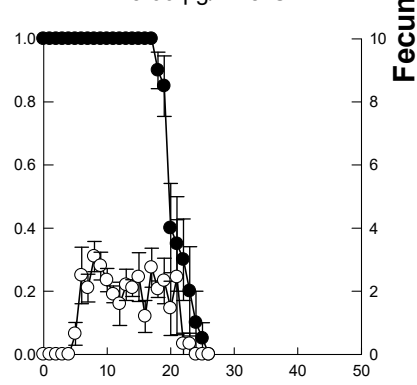

Figure 3. Survivorship and fecundity patterns of Daphnia pulex exposed to cyanobacterial extracts from blooms of Microcystis (January) and Woronichinia (September) at $20^{\circ} \mathrm{C}$ and $25^{\circ} \mathrm{C}$. Shown are mean $\pm \mathrm{SE}$ based on four replicate recordings.

At $25{ }^{\circ} \mathrm{C}$, the average life span, life expectancy at birth and generation time of Daphnia pulex exposed to the extracts from Microcystis-dominant blooms collected in January was significantly lower ( $p<0.05$, one-way ANOVA) in the presence of either concentration of microcystins, as compared to the controls. For gross and net reproductive rates, a hormetic effect was observed where these parameters were elevated at lower concentrations of microcystins as compared to the control ( $p<0.05$, one-way ANOVA). The population growth rates ranged from 0.15 to $0.35 \mathrm{~d}^{-1}$ and were significantly higher in the presence of the microcystins than in the controls ( $p<0.05$, one-way ANOVA) (Figure 5). 


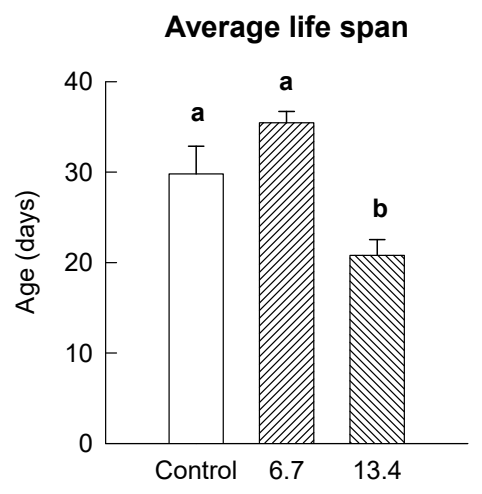

Net reproductive rate
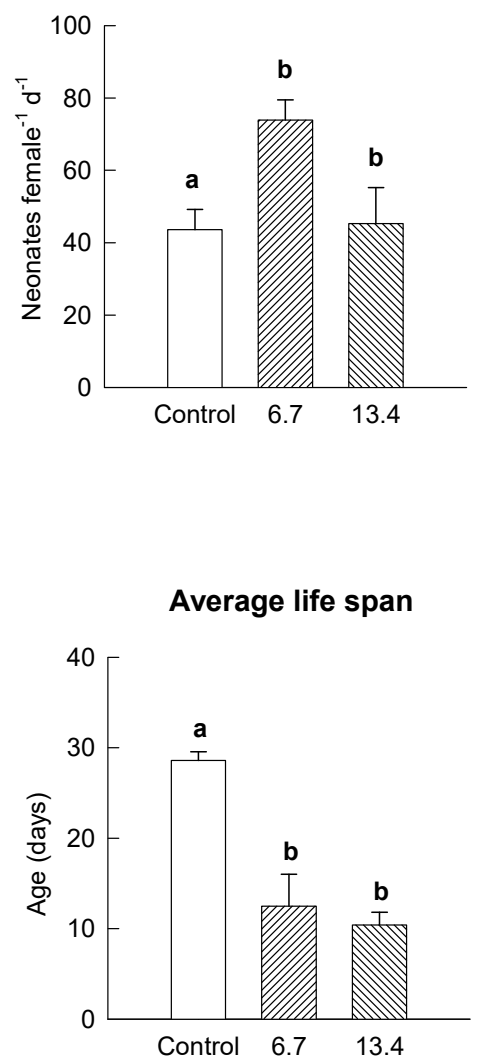

Net reproductive rate

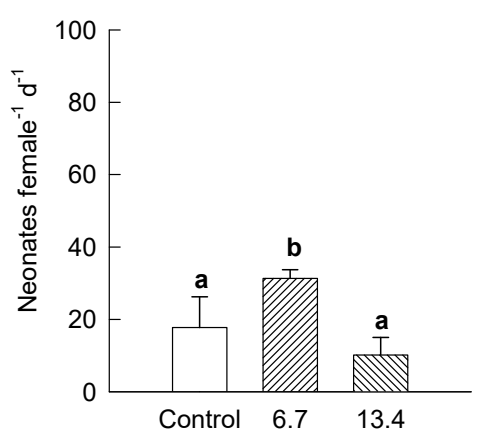

$20^{\circ} \mathrm{C}$

Life expectancy

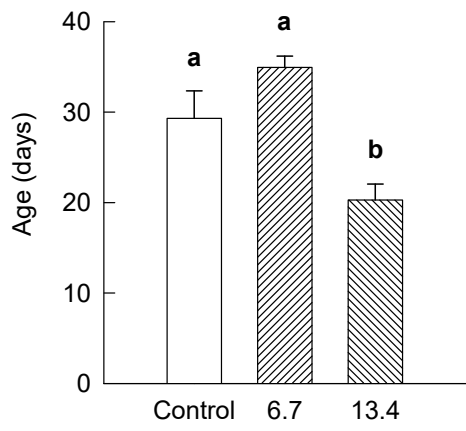

Generation time

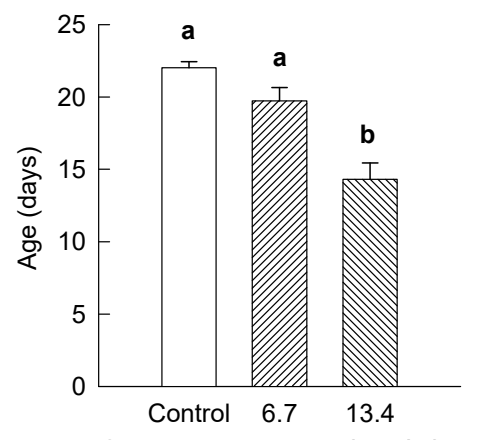

Concentration $(\mu \mathrm{g} / \mathrm{L})$

$25^{\circ} \mathrm{C}$

Life expectancy

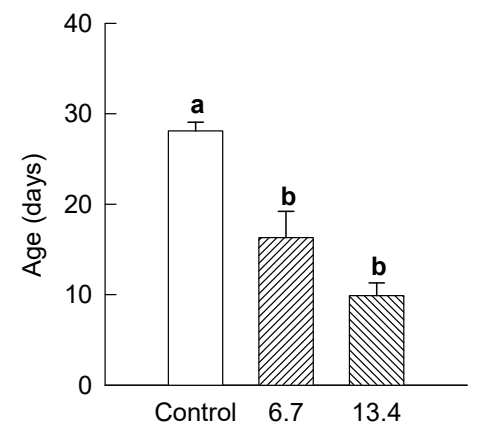

Generation time

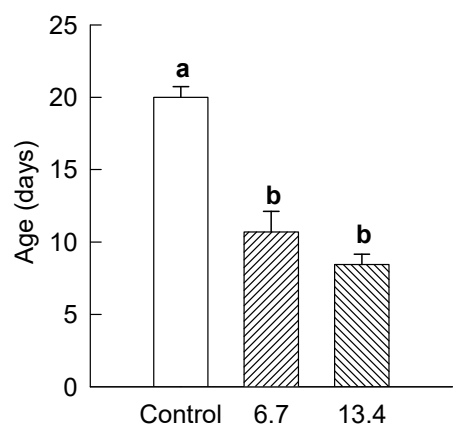

Gross reproductive rate

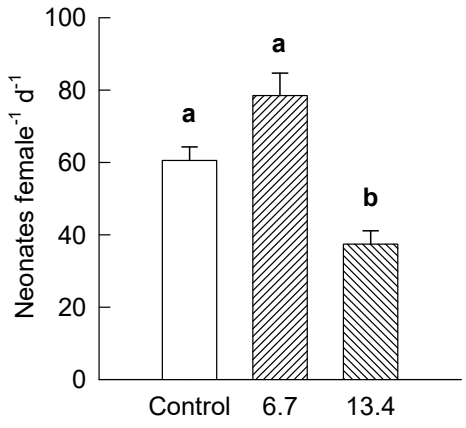

Population growth rate

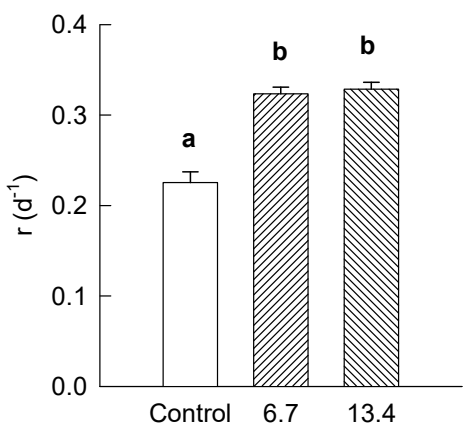

Gross reproductive rate

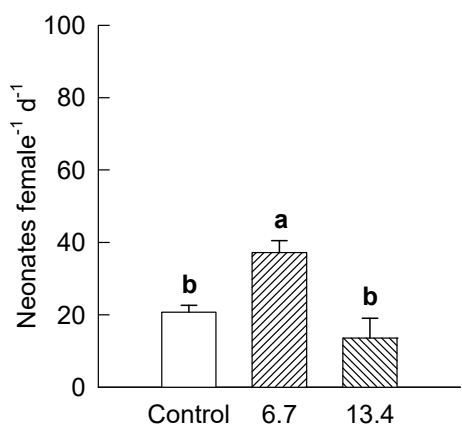

Population growth rate

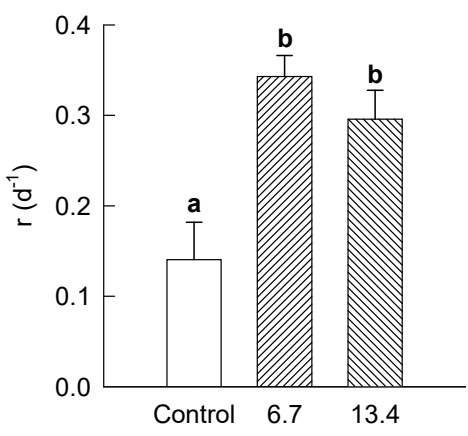

Concentration $(\mu \mathrm{g} / \mathrm{L})$

Figure 4. Life history variables of Daphnia pulex exposed to cyanobacterial extracts from blooms of Microcystis (January) at $20^{\circ} \mathrm{C}$ and $25^{\circ} \mathrm{C}$. Shown are the means \pm SE based on four replicate recordings. Data bars carrying different alphabets for a given variable are significantly different $(p<0.05)$. 
$20^{\circ} \mathrm{C}$

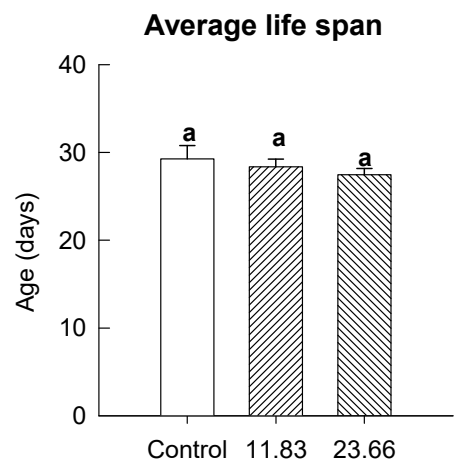

Net reproductive rate

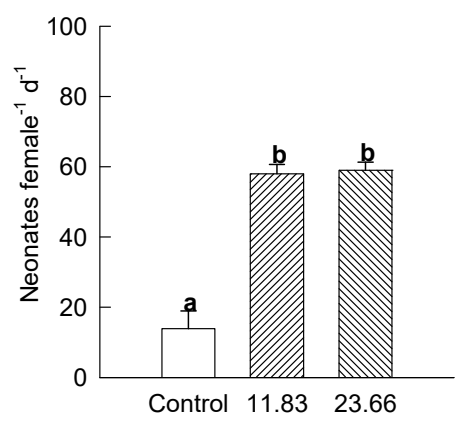

Average life span

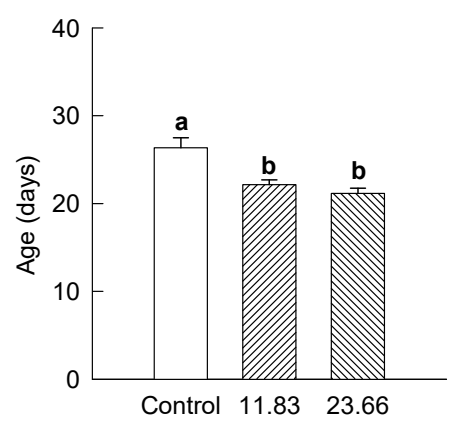

Net reproductive rate

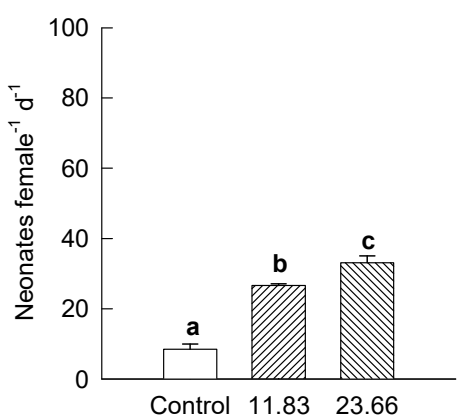

Life expectancy

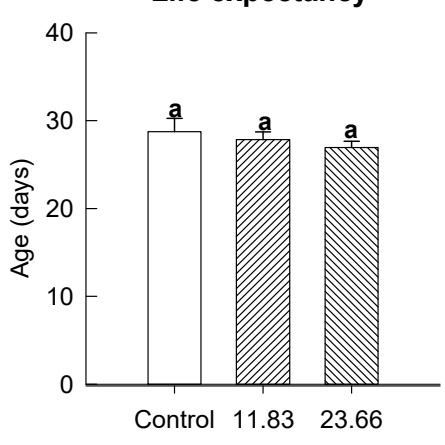

Generation time

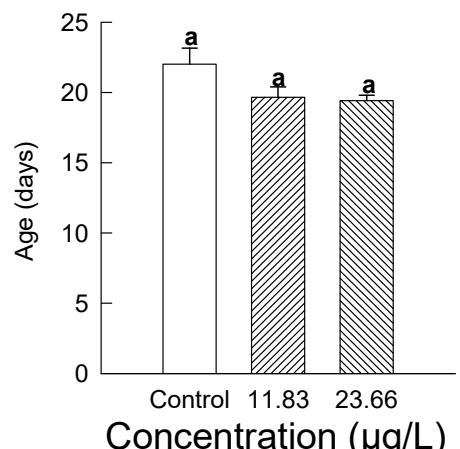

$25^{\circ} \mathrm{C}$

Life expectancy

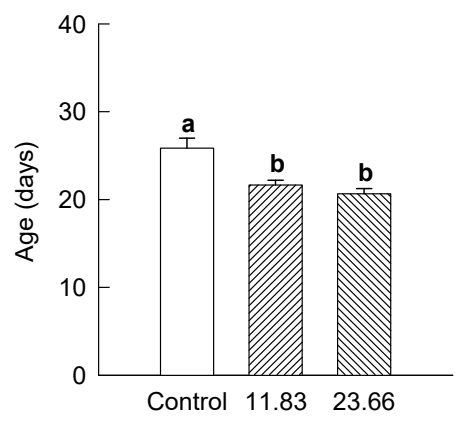

Generation time

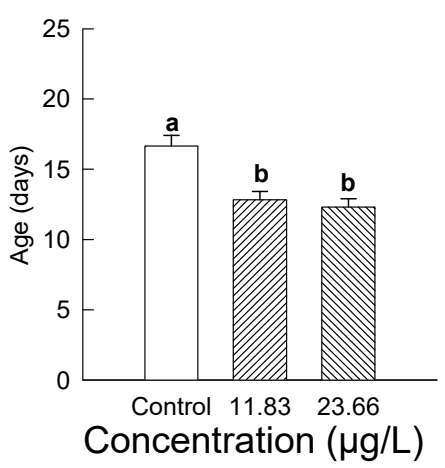

Gross reproductive rate

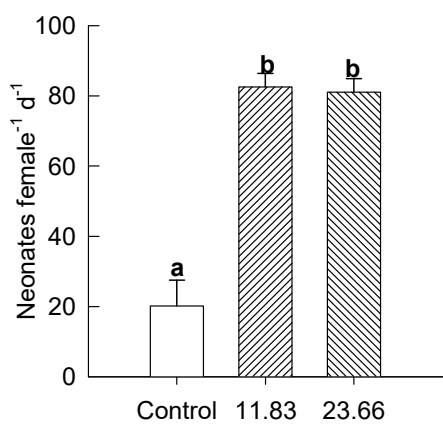

Population growth rate

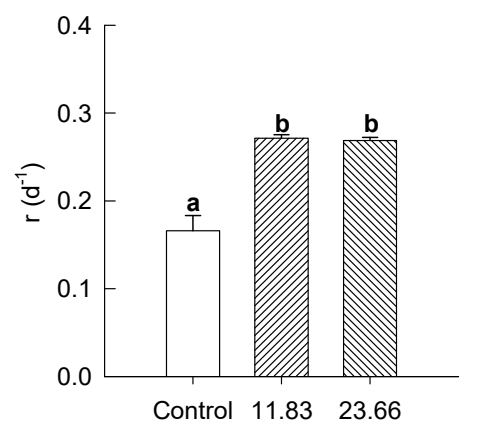

Gross reproductive rate

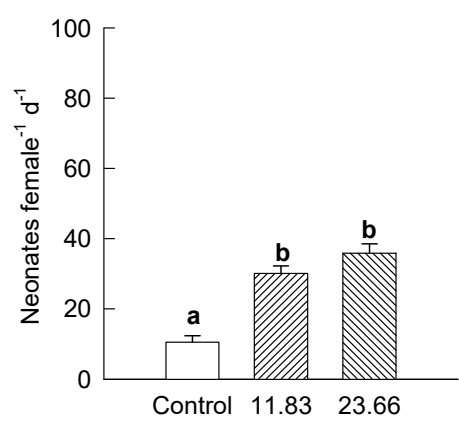

Population growth rate

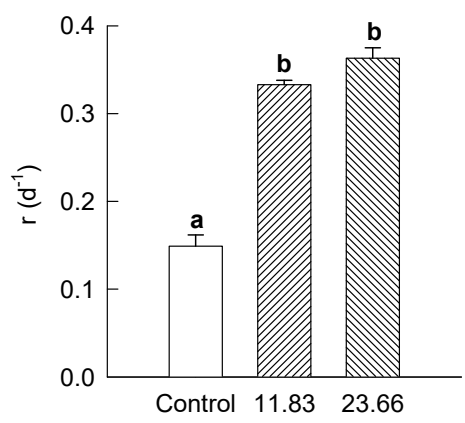

Figure 5. Life history variables of Daphnia pulex exposed to cyanobacterial extracts from blooms of Woronichinia (September) at $20^{\circ} \mathrm{C}$ and $25^{\circ} \mathrm{C}$. Shown are the means \pm SE based on four replicate recordings. Data bars carrying different alphabets for a given variable are significantly different $(p<0.05)$. 
The extracts from Woronichinia-dominant blooms had no adverse effect on the average life span, life expectancy at birth or the generation time at $20^{\circ} \mathrm{C}(p>0.05$, one-way ANOVA). On the other hand, at both the concentrations of the cyanotoxins tested, we observed a significant positive effect on the gross and net reproductive rates, generation time and population growth rate, as compared to the controls ( $p<0.05$, one-way ANOVA) (Figure 4 )

At $25{ }^{\circ} \mathrm{C}$, the average life span, life expectancy at birth and the generation time decreased significantly, as compared to the controls ( $p<0.05$, one-way ANOVA), at both the lower and higher test concentrations of the cyanotoxins (Figure 4). The gross and net reproductive rates, the generation time and population growth rate, however, showed a significant increase as compared to the controls at both test concentrations of the cyanotoxins $(p<0.05$, one-way ANOVA).

\section{Discussion}

The effect of cyanotoxins on zooplankton has been tested using extracts from cyanobacterial cultures [10] and from purified cyanotoxins, mostly microcystins and cylindrospermopsin $[5,25]$. However, during the last decade, studies have also been conducted on the effect of extracts from natural cyanobacterial blooms $[8,11,12]$. Blooms in nature are often dominated by one cyanobacterium but are rarely exclusively a single species; they often consist of several species with one, or a few of them, being dominant. For instance, blooms in Valle de Bravo are often dominated by Microcystis aeruginosa or M. flos-aquae but large numbers of M. wesenbergi, Dolichospermum, Lyngbya and Woronichinia can also be found. The species produce different cyanotoxins which may have synergistic or antagonistic effects. Therefore, studying the effects of extracts from blooms is important because the results can be extrapolated to nature more effectively than those based on purified cyanotoxins which are not available in natural conditions.

Several cyanobacterial species have been cultured in controlled conditions, including those from Microcystis, Lyngbya, Cylindrospermopsis and Dolichospermum [10,26]. However, some species are difficult to culture in the laboratory and this is the case for Woronichinia naegeliana [7]. We found that this species dominated the blooms in September during the study period. A previous study [12] showed that extracts from W. naegeliana-dominated blooms were highly toxic to the rotifer B. calyciflorus. Daphnia pulex, in our study as well as that of Bober and Bialczyk [7], on the other hand, was not sensitive to toxins in aqueous extracts from Woronichinia and, in fact, had higher growth rates in the presence of the extracts than in the controls. Woronichinia is known to produce microginins (MG-FR3) but these did not adversely affect the cladocerans [7]. Studies on the ecotoxicological effects of $W$. naegeliana are important since pure laboratory cultures of this cyanobacterium do not exist [27].

Some studies indicate that zooplankton genera such as Daphnia and Brachionus can utilize the extracts as a source of nutrition, as has been shown by Luo et al. [28], from laboratory cultures of cyanobacteria, and Zamora-Barrios et al. [11], using cyanobacteria extracts from Lake Texcoco (Mexico). Field studies have also indicated that microcystins are not always toxic to zooplankton [29,30]. These findings also highlight the importance of studying different species, since the responses of all zooplankton to cyanotoxins are not similar [31,32]. Data on the demography of Daphnia laevis on Microcystis from the Valle de Bravo reservoir also showed that this daphniid showed positive growth rates on the cyanobacterial diet [31].

Population growth and life-table demography experiments provide complementary information with regard to the responses of zooplankton to stress. Population growth rates were greater in controls than in the presence of extracts under all conditions except at high concentrations of Woronichinia extracts at $25{ }^{\circ} \mathrm{C}$. Similar trends were observed in the demography experiments, in which the survivorship consistently decreased with increasing concentrations of cyanotoxins, regardless of the temperature or the dominance of Microcystis or Woronichinia. On the other hand, the gross reproductive rate was higher in the presence of Woronichinia extracts than Microcystis extracts, as compared to the controls. 
Overall, we found that Daphnia pulex was more sensitive to secondary metabolites from Microcystis than to those from Woronichinia. Nevertheless, these extracts were not lethal to the strain of Daphnia used here. Wojtal-Frankiewicz et al. [33] have shown that Daphnia capable of activating genes to produce glutathione in the presence of microcystins can survive in spite of the toxicant since glutathione binds with microcystin and reduces its toxicity. Thus, strains for which genes signal the production of antioxidants in the presence of stressors may survive in the presence of toxicants.

The life-table studies also showed that Daphnia, a genus normally adapted to temperate climates, had higher survivorship and fecundity at $20^{\circ} \mathrm{C}$ than at $25^{\circ} \mathrm{C}$. With regard to the toxicant concentration, the survivorship decreased with increasing levels at both the tested temperatures and cyanobacteria genera. Fecundity, on the other hand, was often higher in the presence of the aqueous extracts. Similar results have been shown in previous studies on Daphnia exposed to extracts from Planktothrix [34]. This may be due to the fact that cyanobacterial extracts provide nutrition to some species. Previous studies on the effects of these extracts on the rotifer Brachionus calyciflorus showed that the Microcystis and Woronichinia extracts are toxic. However, similar to the results observed here, several studies have indicated that the response of different strains and taxa of zooplankton to cyanotoxins may vary considerably $[11,35]$.

\section{Conclusions}

Our study showed that the demographic response of Daphnia to cyanobacterial extracts vary depending on the temperature and the predominant taxa in the bloom. Daphnia, being better adapted to cooler temperatures, was more adversely affected at $25^{\circ} \mathrm{C}$ than $20^{\circ} \mathrm{C}$. The adverse effect of cyanobacterial extracts was greater for Microcystis than Woronichinia blooms. Our previous study [12] showed the reverse to be true for the rotifer B. calyciflorus. This corroborates the findings of previous work that showed that various species respond differently to cyanobacterial crude extracts and highlights the importance of using a battery of test species for assays.

Author Contributions: Conceptualization, S.N and S.S.S.S.; methodology, C.S.-Z; formal analysis, S.N., C.S.-Z., S.S.S.S., investigation, C.S.-Z; resources, S.N., S.S.S.S.; data curation, S.N, C.S.-Z.; writing—original draft preparation, S.N., C.S.-Z., S.S.S.S.; writing—review and editing, S.N., C.S.Z., S.S.S.S.; visualization, S.N., S.S.S.S.; supervision, S.N.; project administration, S.N.; funding acquisition, S.N. All authors have read and agreed to the published version of the manuscript.

Funding: SN and SSSS thank PAPIIT, UNAM (IN219218 and IG200820) and CONACyT (SNI-20520 and 18723). CSZ thanks CONACyT for a fellowship awarded through the program of assistants to SNI III members (SN, 20520).

Institutional Review Board Statement: Not applicable for studies involving zooplankton.

Informed Consent Statement: Not applicable.

Data Availability Statement: The data presented in this study will be made available on request from the corresponding author.

Conflicts of Interest: The authors declare no conflict of interest. The funders had no role in the design of the study; in the collection, analyses, or interpretation of data; in the writing of the manuscript, or in the decision to publish the results.

\section{References}

1. Gaytan-Herrera, M.L.; Martinez-Almeida, V.; Oliva-Martinez, M.G.; Duran-Díaz, A.; Ramirez-Garcia, P. Temporal variation of phytoplankton from the tropical reservoir Valle de Bravo, Mexico. J. Environ. Biol. 2011, 32, 117-126.

2. Alillo-Sánchez, J.L.; Gaytán-Herrera, M.L.; Martínez-Almeida, V.M.; Ramírez-García, P. Microcystin-LR equivalents and their correlation with Anabaena spp. in the main reservoir of a hydraulic system of Central Mexico. Inland Waters 2014, 4, 327-336. [CrossRef]

3. Figueroa-Sanchez, M.A.; Nandini, S.; Sarma, S.S.S. Zooplankton community structure in the presence of low levels of cyanotoxins: A case study in a high altitude tropical reservoir (Valle de Bravo, Mexico). J. Limnol. 2014, 73, 157-166. [CrossRef] 
4. Zamora-Barrios, C.A.; Nandini, S.; Sarma, S.S.S. Bioaccumulation of microcystins in seston, zooplankton and fish: A case study in Lake Zumpango, Mexico. Environ. Pollut. 2019, 249, 267-276. [CrossRef] [PubMed]

5. Huang, L.; Xi, Y.; Xu, X.; Wen, X. Responses in population growth and reproduction of the freshwater rotifer Brachionus calyciflorus to microcystin-LR at different temperatures. Ann. Limnol. Int. J. Limnol. 2012, 48, 383-390. [CrossRef]

6. Pawlik-Skowrońska, B.; Toporowska, M.; Mazur-Marzec, H. Effects of secondary metabolites produced by different cyanobacterial populations on the freshwater zooplankters Brachionus calyciflorus and Daphnia pulex. Environ. Sci. Pollut. Res. 2019, 26, 1179311804. [CrossRef]

7. Bober, B.; Bialczyk, J. Determination of the toxicity of the freshwater cyanobacterium Woronichinia naegeliana (Unger) Elenkin. J. Appl. Phycol. 2017, 29, 1355-1362. [CrossRef]

8. Okumura, D.; Sotero-Santos, R.; Takenaka, R.; Rocha, O. Evaluation of cyanobacteria toxicity in tropical reservoirs using crude extracts bioassay with cladocerans. Ecotoxicology 2007, 16, 263-270. [CrossRef] [PubMed]

9. Pietsch, C.; Wiegand, C.; Áme, V.; Nicklish, A.; Wunderlin, D.; Pflugmacher, S. The effects of cyanobacterial crude extract on different aquatic organisms: Evidence for cyanobacterial toxin modulating factors. Environ. Toxicol. 2001, 16, 535-542. [CrossRef]

10. Zamora Barrios, C.A.; Nandini, S.; Sarma, S.S.S. Effect of crude extracts of Dolichospermum planctonicum on the demography of Plationus patulus (Rotifera) and Ceriodaphnia cornuta (Cladocera). Ecotoxicology 2015, 24, 85-93. [CrossRef] [PubMed]

11. Zamora Barrios, C.A.; Nandini, S.; Sarma, S.S.S. Effect of crude extracts from cyanobacterial blooms in Lake Texcoco (Mexico) on the population growth of Brachionus calyciflorus (Rotifera). Toxicon 2017, 139, 45-53. [CrossRef]

12. Nandini, S.; Sánchez-Zamora, C.; Sarma, S.S.S. Toxicity of cyanobacterial blooms from the reservoir Valle de Bravo (Mexico): A case study on the rotifer Brachionus calyciflorus. Sci. Total Environ. 2019, 688, 1348-1358. [CrossRef] [PubMed]

13. Nandini, S.; Zamora-Barrios, C.A.; Sarma, S.S.S. A Long-Term Study on the Effect of Cyanobacterial Crude Extracts from Lake Chapultepec (Mexico City) on Selected Zooplankton Species. Environ. Toxicol. Chem. 2020, 39, 2409-2419. [CrossRef] [PubMed]

14. Sarma, S.S.S.; Peredo-Alvarez, V.M.; Nandini, S. Comparative study of the sensitivities of neonates and adults of selected cladoceran (Cladocera: Crustacea) species to acute toxicity stress. J. Environ. Sci. Health 2007, 42A, 1449-1452. [CrossRef]

15. Ramírez-García, P.; Nandini, S.; Sarma, S.S.S.; Robles-Valderrama, E.; Cuesta, I.; Hurtado, M.D. Seasonal variation of zooplankton abundance in the freshwater reservoir Valle de Bravo (Mexico). Hydrobiologia 2002, 467, 99-108. [CrossRef]

16. Sarma, S.S.S.; Nandini, S. Review of recent ecotoxicological studies on cladocerans. J. Environ. Sci. Health 2006, 41B, 1417-1430. [CrossRef] [PubMed]

17. Nandini, S.; Merino-Ibarra, M.; Sarma, S.S.S. Seasonal changes in the zooplankton abundances of the reservoir Valle de Bravo (State of Mexico, Mexico). Lake Reserv. Manag. 2008, 24, 321-330. [CrossRef]

18. Miracle, M.R.; Nandini, S.; Sarma, S.S.S.; Vicente, E. Endocrine disrupting effects, at different temperatures, on Moina micrura (Cladocera: Crustacea) induced by carbendazim, a fungicide. Hydrobiologia 2011, 668, 155-170. [CrossRef]

19. Komárek, J.; Anagnostidis, K. Cyanoprokaryota. 1. Teil: Chroococcales. In Süßwasserflora von Mitteleuropa, 19/1; Ettl, H., Gärtner, G., Heynig, H., Mollenhauer, D., Eds.; Gustav Fischer: Jenna, Germany, 1999; 548p.

20. Wehr, J.D.; Sheath, R.G.; Kociolek, J.P. Freshwater algae of North America: Ecology and classification; Academic Press: New York, NY, USA; Elsevier: Amsterdam, The Netherlands, 2003; 917p.

21. Borowitzka, M.A.; Borowitzka, L.J. Micro-algal Biotechnology; Cambridge University Press: London, UK, 1998; 488p.

22. Weber, C.I. Methods for Measuring the Acute Toxicity of Effluents and Receiving Waters to Freshwater and Marine Organisms, 4th ed.; Environmental Protection Agency (EPA): Cincinnati, OH, USA, 1993; 293p.

23. Finney, D.J. Probit Analysis, 3rd ed.; Cambridge University Press: London, UK, 1971.

24. Krebs, C.J. Ecology: The Experimental Analysis of Distribution and Abundance, 3rd ed.; Harper and Row: New York, NY, USA, 1985; $694 \mathrm{p}$.

25. Kinnear, S. Cylindrospermopsin: A decade of progress on bioaccumulation research. Mar. Drugs 2010, 8, 542-564. [CrossRef]

26. Notch, E.G.; Miniutti, D.M.; Berry, J.P.; Mayer, G.D. Cyanobacterial LPS potentiates cadmium toxicity in zebrafish (Danio rerio) embryos. Environ. Toxicol. 2011, 26, 498-505. [CrossRef]

27. Stefanelli, M.; Scardala, S.; Cabras, P.A.; Orrù, A.; Vichi, S.; Testai, E.; Funari, E.; Manganelli, M. Cyanobacterial dynamics and toxins concentrations in Lake Alto Flumendosa, Sardinia, Italy. Adv. Oceanogr. Limnol. 2017, 8, 71-86. [CrossRef]

28. Luo, X.; Liu, Z.; Gulati, R.D. Cyanobacterial carbon supports the growth and reproduction of Daphnia: An experimental study. Hydrobiologia 2015, 743, 211-220. [CrossRef]

29. Sarnelle, O.; Gustafsson, S.; Hansson, L.A. Effects of cyanobacteria on fitness components of the herbivore Daphnia. J. Plankton Res. 2010, 32, 471-477. [CrossRef]

30. Chen, Y.; Zhang, L.; Jiang, X. Fine-scale local adaptation of cyanobacterial tolerance in Simocephalus vetulus (Crustacea: Cladocera). J. Plankton Res. 2015, 37, 764-772. [CrossRef]

31. Nandini, S.; Sarma, S.S.S.; Ramírez-García, P. Life table demography and population growth of Daphnia laevis (Cladocera) under different densities of Chlorella vulgaris and Microcystis aeruginosa. Crustaceana 2000, 73, 1273-1286. [CrossRef]

32. Wilson, A.E.; Sarnelle, O.; Tillmanns, A.R. Effects of cyanobacterial toxicity and morphology on the population growth of freshwater zooplankton: Meta-analyses of laboratory experiments. Limnol. Oceanogr. 2006, 51, 1915-1924. [CrossRef]

33. Wojtal-Frankiewicz, A.; Bernasińska, J.; Jurczak, T.; Gwoździński, K.; Frankiewicz, P.; Wielanek, M. Microcystin assimilation and detoxification by Daphnia spp. in two ecosystems of different cyanotoxin concentrations. J. Limnol. 2013, 72, 154-171. [CrossRef] 
34. Hulot, F.D.; Carmignac, D.; Legendre, S.; Yepremian, C.; Bernard, C. Effects of microcystin-producing and microcystin-free strains of Planktothrix agardhii on long-term population dynamics of Daphnia magna. Ann. Limnol. Int. J. Lim. 2012, 48, 337-347. [CrossRef]

35. Nandini, S. Responses of rotifers and cladocerans to Microcystis aeruginosa (Cyanophyceae): A demographic study. Aquat. Ecol. 2000, 34, 227-242. [CrossRef] 